\title{
Innovative Laser Technology In Textile Industry: Marking and Engraving
}

\author{
Yordanka Angelova ${ }^{1}$, Lyubomir Lazov ${ }^{2}$, Silvija Mezinska ${ }^{2}$ \\ Technical University of Gabrovo, 4.H.Dimiter Str., 5300 Gabrovo, Bulgaria ${ }^{1}$, \\ Rezekne Academy of Technologies, Faculty of Engineering, Atbrivosanas aleja 115, Rezekne, Latvia ${ }^{2}$
}

\begin{abstract}
The advent of laser technology in textiles industry has established a new innovative solution, which successfully prevents some of the weaknesses in the conventional technologies. Lasers are being used in Laser Marking (Only the surface of fabric is processed, fading), Laser Engraving (Controlled cutting to depth). It has been used extensively as the replacement of some conventional dry processes like sand blasting, hand sanding, destroying, and grinding etc., which are potentially harmful and disadvantageous for the environment.

The article considers some innovative laser technologies, such as marking and engraving on various textile materials. The laser applications for leather and textile processing were analysed. The report overviews systems and ways of laser marking and engraving implementations. Classification of markings was proposed. The advantages of laser marking and engraving technologies in textile fields were pointed.
\end{abstract}

Keywords: laser technologies, marking, engraving, textiles, denim clothing.

\section{INTRODUCTION}

Laser marking and engraving are innovative technologies. Furthermore, they discover additional horizons for the textile sector by providing prospects for development of new production technologies [4, 38 , 39]. Laser technologies take place on modern laser systems on fabric, ready-made clothes, logos, labels and others. Some information (alpha-numeric, graphics or encoded) is applied to almost all types of materials including textiles and leather. It is an important element in the modern manufacture and consumption of goods with certain functions: identification, information, warning, aesthetic, etc.

In recent years, the use of lasers for textile material marking is increasing because of the speed, accuracy and flexibility of this modern technique [29]. Many traditional methods of textile and clothing finishing consume significant energy amounts, water and other supplies. Compared to them, the laser technology is adequate to achieve good results at low cost. The laser methods are used extensively as a replacement of some conventional processes which are ones of the most environment polluting technologies, potentially harmful and disadvantageous in some manner [16, 26, 34].

Laser technologies, such as marking and engraving are considered in this article. Applications of laser for various textile material processing are analysed. The report overviews systems and ways of laser marking and engraving implementations. The advantages of laser marking and engraving technologies in textile fields are pointed.

\section{WAYS OF LASER MARKING AND ENGRAVING IMPLEMENTATION}

Laser marking and engraving are implemented through three main ways: raster, vector and projection. When image is obtained by raster marking, laser beam moves sequentially in rows, similar to dot matrix printers, but instead of an ink there is a laser beam "Fig.1". This method was used mainly for marking alpha-numeric information, more rarely for graphic images $[2,8,22,24]$.

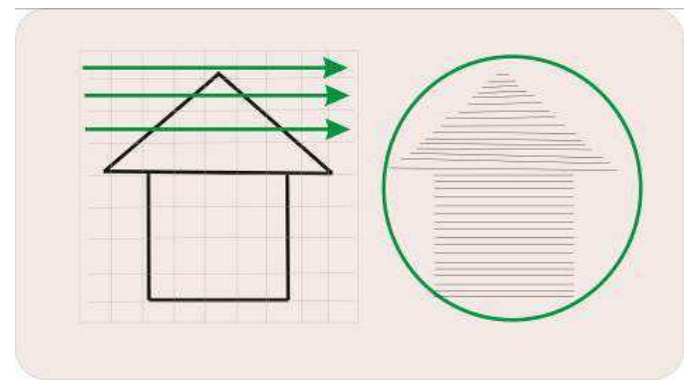

Fig. 1. Way of Raster Marking

In vector marking the mark is written by focused laser beam, which follows the contour, guided by an optical system, operated by a computer program "Fig. 2". Vector marking applies to all kinds of information: numeric-codes, bar-codes, 2D codes, logos, and almost any other type of image. This is the most common and versatile method of laser marking. 


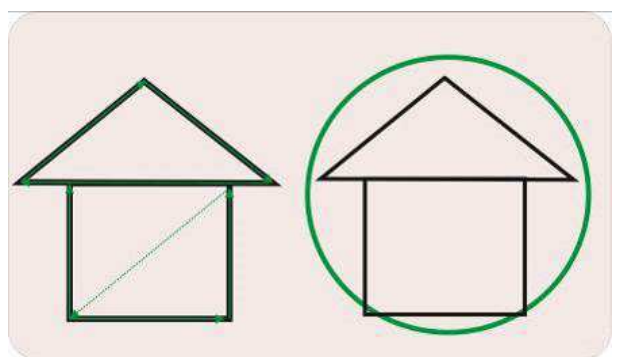

Fig. 2. Way of Vector Marking

Projection marking is implemented with mask (stencil). Laser beam passes through it and is projected onto the working area "Fig. 3".

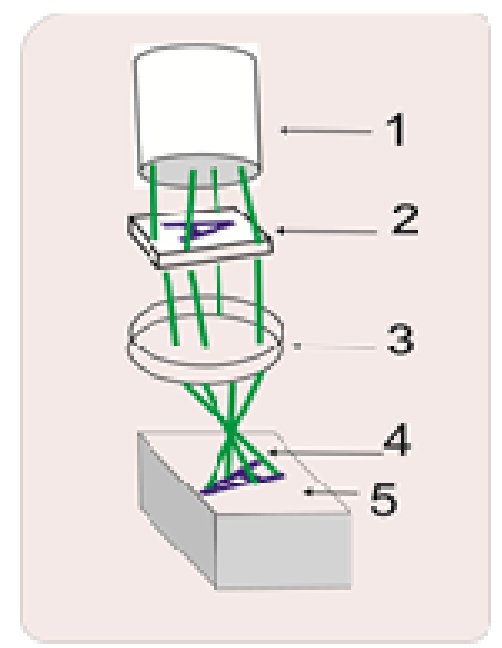

Fig. 3. Projection Marking

where: 1-laser, 2-mask, 3-lens, 4-image, 5-work area [3].

Raster and vector marking can be realized by a plotter "Fig. 4" or a scanner system "Fig. 5".

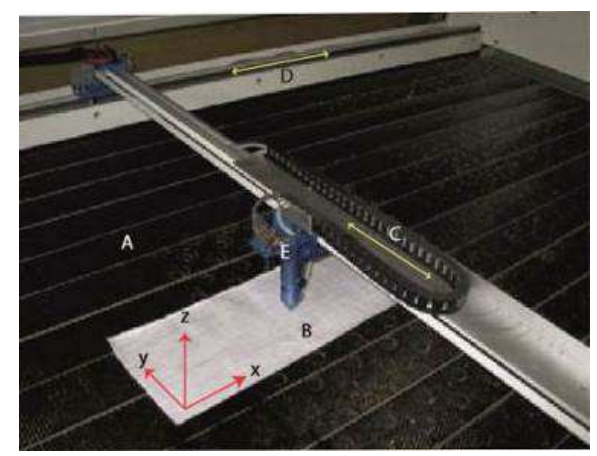

Fig. 4. Plotter system for marking [25]

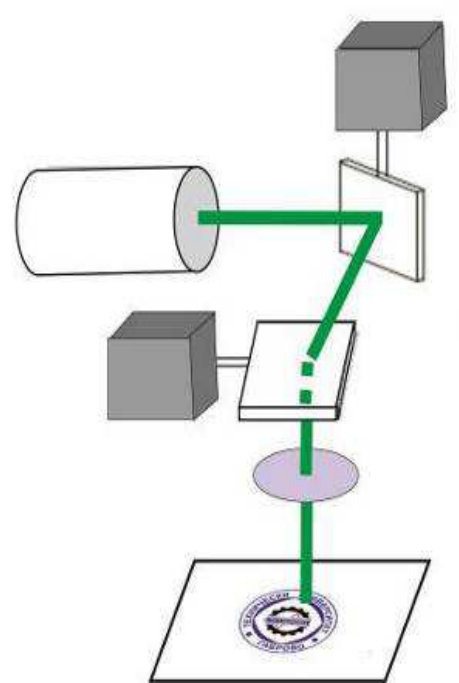

Fig. 5. Scanner system for marking [3].

Systems that combine plotter and scanner system are used increasingly "Fig.6" [8, 22, 24]. Each of the three systems for laser marking has its advantages and disadvantages. According to the specific case of marking the most appropriate way is selected depending on the requirements for speed, size of the treated area, flexibility and investment costs.

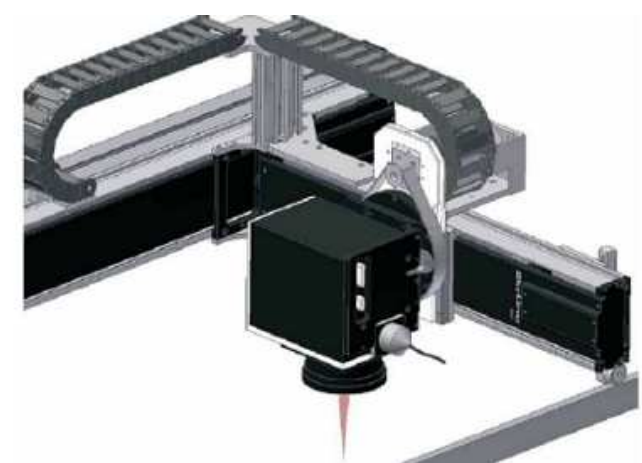

Fig. 6. Plotter\&scanner system for marking.

\section{FACTORS INFLUENCING THE QUALITY OF LASER MARKING}

In order to achieve the best marking results, it is necessary to obtain optimum combination of laser parameters and parameters of the technological process for the relevant material. The main factors that influence, to a greater or lesser extent, the quality of marking may be presented in the following groups, relating respectively to: the properties of the material for marking, the parameters of the laser source (laser properties) and parameters of the technological process $[2,3,10]$. 


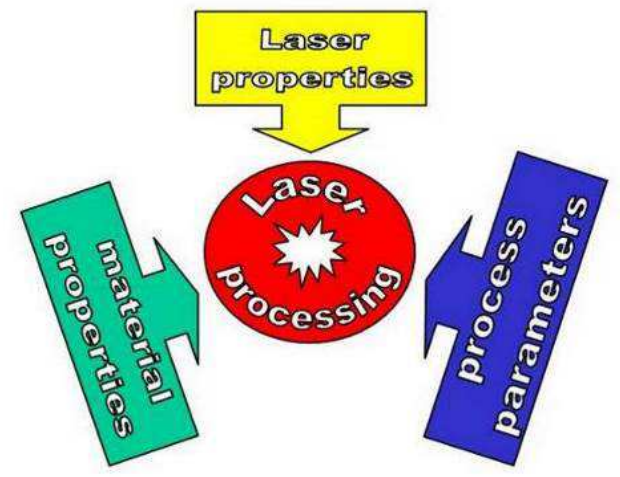

Fig. 7. Factors that influence laser technology in the textile industry [10]

Optical characteristics of different materials, as: reflectance capacity, absorption capacity, transmission efficiency, relevant coefficient and their interconnection are basic to the process of laser marking. Heat transfer in treated area of the material takes place during the laser marking process. Therefore, it is essential to have knowledge of its main thermal-physical properties: coefficient of thermal conductivity, specific heat capacity, ratio of temperature-conductivity. Textile material and leathers behaviour to heating is very important for setting up laser system in order to obtain the desired results.

The variety of textile materials is vast. In general, they can be divided into two groups: of natural origin (such as cotton, wool, etc.) and synthetic (polyester, polyamide, etc.). The key is to know their properties very well, especially what happens when they are admitted to heat in different temperatures.

For example: The cellulose (the content of cotton is about $91-95 \%$ cellulose) carbonizes (burns) without melting at high temperature. Thermal destruction occurs from $150^{\circ} \mathrm{C} \div 180^{\circ} \mathrm{C}$, the fibre strength decreases significantly and the color changes. As a result of cellulose destruction, the polymer chain breaks, as its length decreases and respectively its average molecular mass reduces. At about $220^{\circ} \mathrm{C}$ the vitrification happens and cellulose passes from viscoelasticity to pseudo-plasticity state. At $300^{\circ} \mathrm{C}$ the result is carbonation. When the polyester fibres heat to temperature $80 \div 90^{\circ} \mathrm{C}$ they vitrificate, at about $250^{\circ} \mathrm{C}$ they become soft and at $260^{\circ} \mathrm{C}$ - melt. When temperature reaches $350^{\circ} \mathrm{C}$ - evaporate [9].

Marking depends on the following characteristics of laser source: wavelength - $\lambda$, the diameter of the minimum focal spot, average power, impulse power, pulse duration, pulse frequency, surface power density of laser radiation impulse power, pulse duration, pulse frequency, surface power density of laser radiation parameter of quality of the laser beam.

From factors related to the technological process, the most crucial are: speed of marking, step of marking, number of repetition and defocusing.

\section{LASER SOURCES FOR TEXTILE MATERIAL MARKING}

A vast variety of laser sources and laser technological systems with different characteristics and application are offered on the world market $[6,7$, 45]. This requires, for a case-by-case basis, to select good quality laser beam with a corresponding wavelength. The wavelength determines good absorption of a specific color material. Technological process of laser marking is complex and to get good results with economically justified costs, it is necessary to find the right laser for corresponding production. Textile polymer marking requires lasers with a wavelength that is absorbed best by the material, low impulse energy and lower power density than used for marking metals. The average power of the laser doesn't have to be high, enough is at the range of $10-50 \mathrm{~W}$. Good results are achieved in diameter of the minimum focal spot about $0.03-0.2$ $\mathrm{mm}$

Basic parameters of some lasers for marking are given in table 1. [2, 35, 41, 42, 45, 46].

Table I

Key features of some lasers, applied for textile and leather materials

\begin{tabular}{|l|ll|c|c|c|c|}
\hline \multirow{2}{*}{ № } & \multirow{2}{*}{ Parameters } & \multicolumn{4}{|c|}{ Type of laser } \\
\cline { 4 - 7 } & & $\mathrm{CuBr}$ & $\mathrm{CO}_{2}$ & Fiber & Excimer \\
\hline 1 & Wavelength of laser & $\lambda, \mu m$ & $0,511-0,578$ & 10,64 & 1,064 & 0,193 \\
\hline 2 & Average power & $\mathrm{P}, W$ & 10 & 50 & $10-40$ & 24 \\
\hline 3 & Impulse power & $\mathrm{P}_{\mathrm{p}}, k W$ & $17-34$ & 10 & $5,32-17,8$ & 1700 \\
\hline 4 & Impulse energy & $\mathrm{E}_{\mathrm{p}}, m J$ & $0,50-1,02$ & 0,20 & $0,16-1,33$ & 24 \\
\hline 5 & Pulse duration & $\tau, n s$ & 30 & 20 & $30-250$ & 14 \\
\hline 6 & Pulse frequency & $\nu, k H z$ & $1-20$ & $0,20-50$ & $20-30$ & 1 \\
\hline 7 & Diameter of the minimum focal spot & $d_{f, m m}$ & 0,03 & 0,15 & 0,15 & 0,2 \\
\hline 8 & Quality of the laser beam & $M^{2}$ & 1,7 & $1,5 \div 2$ & 1,1 & 2 \\
\hline 9 & Positioning accuracy & $\mu \mathrm{m}$ & $<2,5$ & $<10$ & $<2,5$ & $<2,5$ \\
\hline 10 & Coefficient of efficiency & $\mathrm{COP}, \%$ & 10 & 20 & 40 & 10 \\
\hline
\end{tabular}

\section{METODS OF LASER MARKING}

Today all organic polymers, such as the textiles and leather, can be treated by one or another manner, by means of laser radiation. When the laser beam is focused on the material, its energy is absorbed by the surface layer, modified in depth from parts of micron to hundreds micron "Fig. 8". As a result of the reaction, caused by heat and according to the type of 
material, different results can be achieved $[15,16$, $25,29]$.

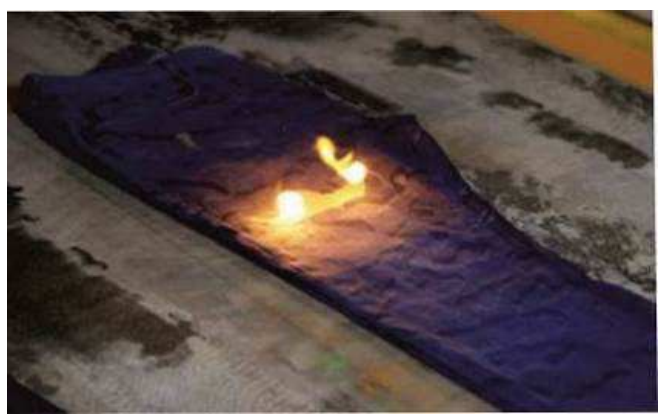

Fig. 8. Laser bleaching on Denim Jeans [21].

Depending on the depth of processing two processes can be distinguished and defined: laser marking and laser engraving. Laser marking is surface impact in very little depth. Laser engraving is impact in much greater depth and most cases besides the color, also relief effect is obtained.

The textile fabrics are more often with small thickness from $0.1 \mathrm{~mm}$ to $5.0 \mathrm{~mm}$ [10]. For them more appropriate is to apply laser marking process. For materials with greater thickness it is recommended to choose engraving process. These kinds of textile, so called 3D fabrics, are woven, knitted or non-woven fabrics and composites. A large part of industrial materials are textile polymer materials.

Laser marking and laser engraving can be realized through a variety of methods, such as:

- change of color by bleaching (depigmentation) "Fig. 11", "Fig. 12";

- change of surface as a result of destruction;

- change of surface as a result of vitrification;

- change of color and structure through carbonation (burning) "Fig. 9a)";

- melting of surface layer material "Fig. 9b)";

- evaporation of surface layer material (ablation) "Fig. 10", "Fig. 14".

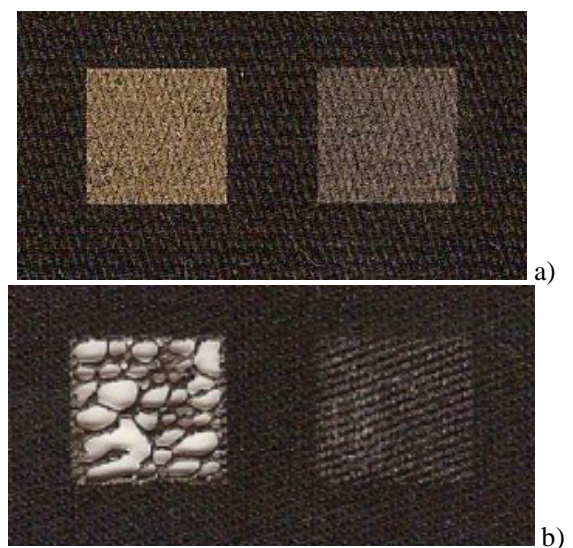

Fig. 9. Laser treating by: a) carbonation; b) melting.

Laser methods become increasingly popular and are applied as a substitute for traditional finishing processes in textile industry nowadays [16,26,34,36]. One of the most workable textile laser treating, especially for denim, is bleaching method [20]. Bleaching (fading) surface of denim fabric by conventional chemical and mechanical processes (sandblasting, stone washing, enzyme washing, bleach washing, grinding and etc.) causes environmental pollution, while laser whitening is an ecologically clean process [18,19,31]. By controlling laser parameters, such as amount of energy applied on the fabric, the color changes on the surface, affecting its appearance without unacceptable damage to the material. The firm 'SEI Laser' presents a revolutionary technology 'Flexi Denim' for laser finishing that can replace traditional methods of manual discoloration, wearing out, decoration, marking, engraving and cutting of jeans and ready-towear clothes, at the textile show ITMA'2015, Milan, Italy. This technology reduces water consumption by $80 \%$ and removes toxic chemicals used for treatment of denim fabrics in traditional methods. It reduces the cost of energy consumption at three times higher performance relative to the conventional methods - to 160 pairs of jeans per hour [32].

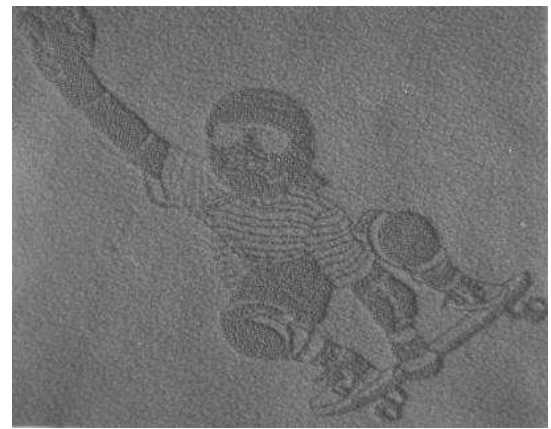

Fig. 10. Laser treating by evaporation (ablation) on polar fabric.

\section{VI.APPLICATIONS OF LASER MARKING AND ENGRAVING}

Laser technologies marking and engraving can be used for different applications. Depending on function for which they are intended, images are: decorative and informative.

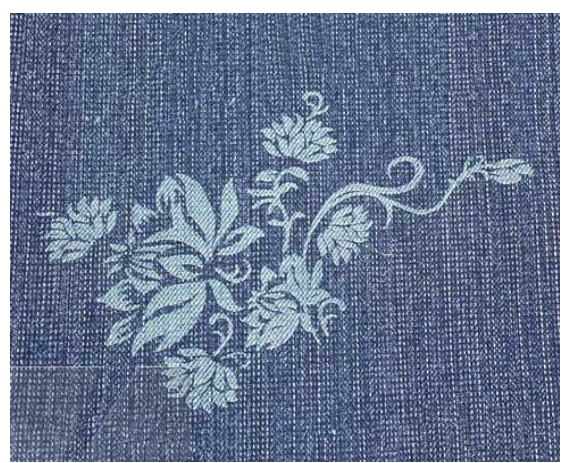

Fig. 11. Graphic design: decorative image at denim reached by the bleaching method [12]. 
Currently decorating clothes with laser is the most economical and creative technology of its artistic meaning. Decorating with the help of laser technology allows to create truly unusual, complicated in many ways and certainly completely unique models in fashion design [37]. Through opportunities for computer controled laser beam and the application of different methods of marking, expression of graphical information, in the art sphere on fabric surfaces, is unlimited actually "Fig. 11".

Laser marking allows obtaining the so-called 3D pictures (paintings) on the fabric. They look very real thanks to the receipt of light and dark areas and numerous shades "Fig.12a [15])"\&"Fig.12c [47])" or whiskers "Fig.12d [26])". It is easy to combine cutting out lace and marking 3-D effects together on jeans "Fig. 12b" [17].

Similar well-known technologies are applying an image screen printing and thermal transfer printing, but they have limitations on the range of materials used and the end result does not provide a completeness of light and shadow transmission [1].
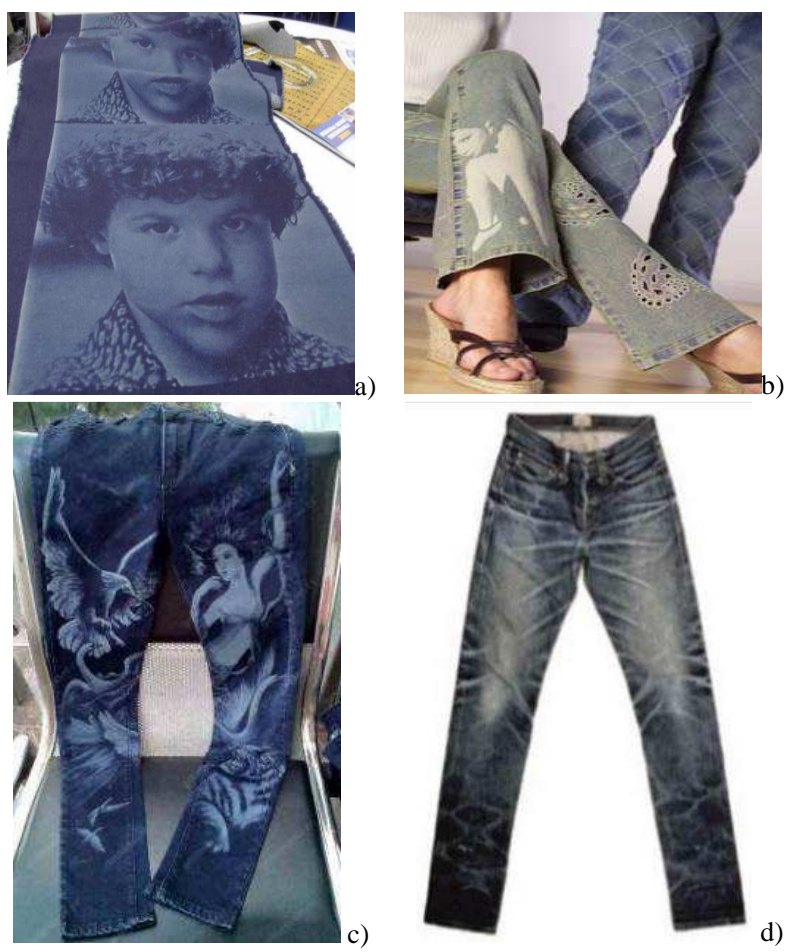

Fig. 12. Laser marking applications by varied of effects at jeans

Also, a very important laser marking application is to express technical information. With the help of laser information on fabric surface is put very easily: signs, identification symbols (letters and digits), bar codes, 2D matrix code "Fig.13" special characters, serial numbers, logos "Fig.14" and so on.

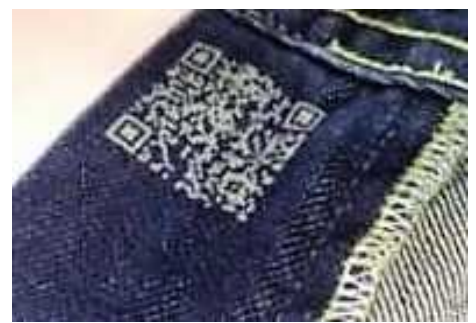

Fig. 13. 2D matrix code directly on the article [44].

About the user, marking comprises all important information on the main characteristics of the product, such as manufacturer identification, size, ingredients, care and maintenance of the product, instructions for possible allergic substances, flammability, environmental requirements and so on [11]. European and world markets require marking as an integral part of the offered products.

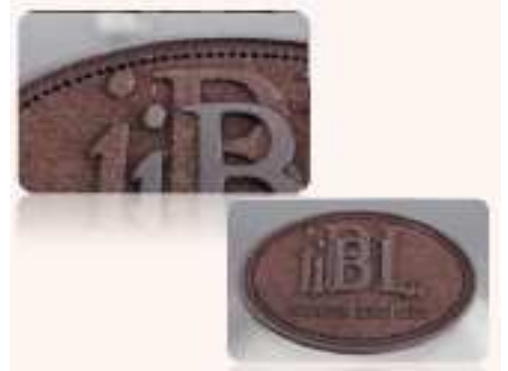

Fig. 14. Laser marking of logo on a leather

On the other hand, for manufacturer, marking is required to control production process-tracing at the stages of creation and removal of defects with the aim of good production quality.

\section{ADVANTAGES OF LASER MARKING}

Laser marking and engraving of textile materials are fundamentally different and greatly superior to conventional. The following advantages can be indicated [2, 8, 30, 32, 33]:

- Automated process of production reporting and control - reading with electronic tracking devices on the marked product during manufacturing process and throughout the retail chain $[5,13,23,30,29,40,43]$;

- Ability to process almost all textile materials;

- Ensure the authenticity of the product and protect it against counterfeiting;

- Allows storage of large amounts of data;

- The density of marked information is very big;

- The ability to read at different angles and even after a partial demolition, which is very typical for textile products during exploitation life;

- Flexibility - integration in production and automated lines allows marking on the fly;

- Extremely accurate and qualitative, with clear contours, very fast and precise method;

- Minimal heat affected zone; 
- Contactless - missing mechanical impact on the treated material, and the result is getting the permanent, contrasting image;

- Very good quality, due to the stability and manageability of the laser source;

- Environmentally friendly process;

- High performance of the process;

- Profitable method as for large series and for single piece;

- Economical - low production and operating costs without the use of consumables, there are not necessary nor chemicals, nor ink ribbons or other materials;
Laser technologies work with better precision and higher productivity but also, they should be optimized and investigated for each specific process and material.

VIII. CLASSIFICATION OF MARKINGS

Marking has various purpose and is made according to the specific requirements.

The classification of marks can be made in different indicators "Fig. 15". Types of markings obtain by laser radiation are a part of the main classification.

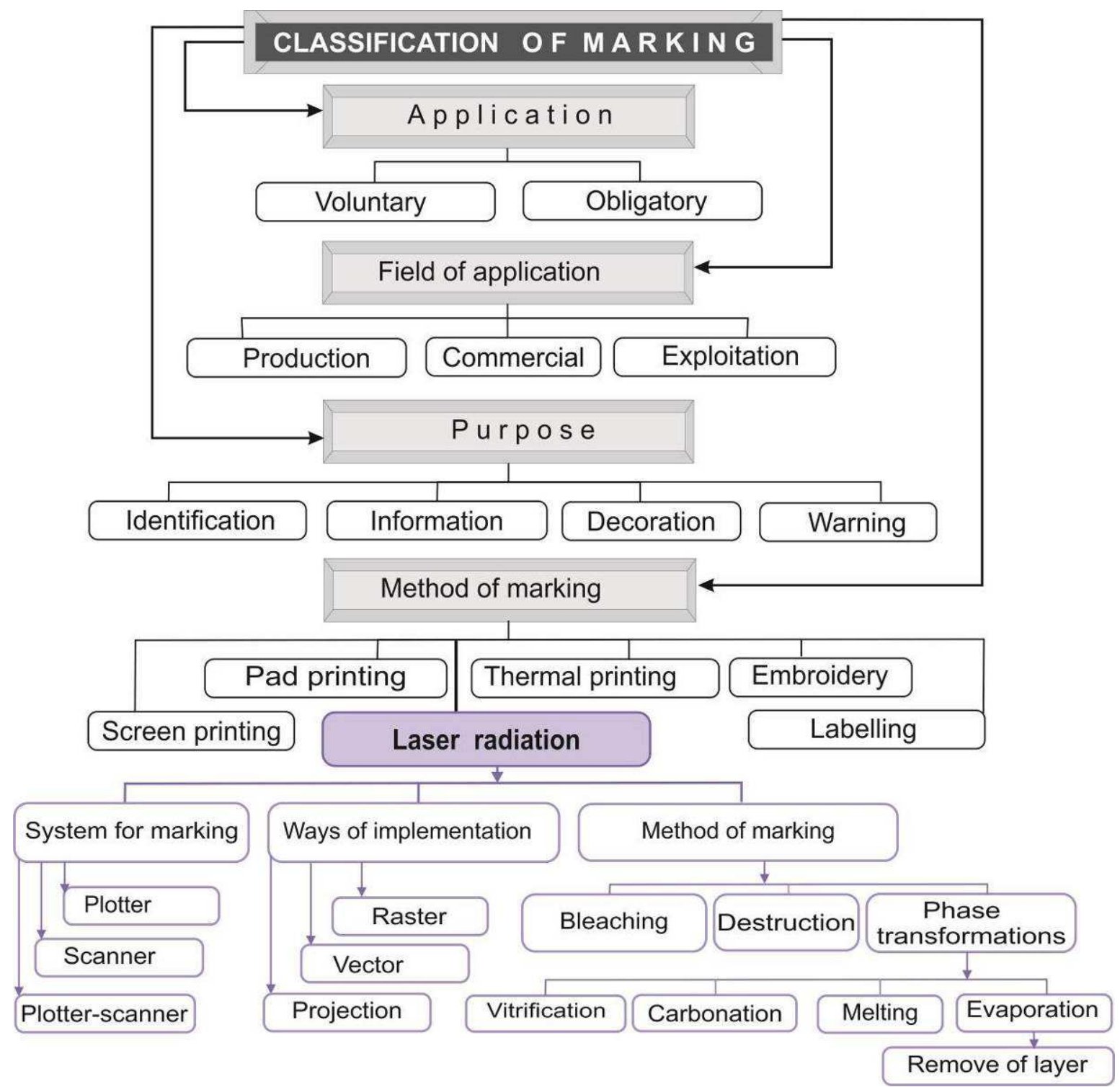

Fig. 15. Classification of the markings by various indicators [3]

IX. CONCLUSIONS

The laser-based marking and engraving are complex physical processes with a great scientific and applied importance. Laser radiation provides high quality processing because of its technical characteristics. Laser marks can be successfully used for artistic decorating and unique design of any surfaces of textile products, so popular in fashion industry.

As well they are used for important, indelible technical information, which is useful for both manufacturers and consumers. Marks contain some 
data about the textile product and allow tracking sources of raw materials, monitoring and controlling the state of proceedings and their impact on the environment.

For all textile materials, also for leather materials, marking and engraving can be successfully applied. The choice of laser process is determined by the desired final result.

In this research, the laser applications for leather and textile processing are analysed. The advantages of innovative laser technology in textile fields were pointed.

\section{REFERENCES}

[1] Абуталипова Л.Н., Гатиятуллина Р.Ф. Модификация поверхности полимерных текстильных материалов под воздействием

[2] Angelov, N., "Optimization of the marking process with a laser radiation of the tool steel specimens ", $\mathrm{PhD}$ Thesis, 2011

[3] Angelova, Y., "Investigation on Laser Marking Process of Industrial Materials", PhD Thesis, 2017.

[4] Angelova, Y.,L.Lazov, "Laser technology in textile industry", 46 International Congress IFKT, 6-8 Sept. 2012, Sinaia, Romania

[5] Валиулин А., С.Горный, Ю.Гречко, М.Патров, К.Юдин, В.Юревич, “Лазерная маркировка материалов”, Научнотехнический журнал Фотоника, № 3/2007, с.16-22, 2007

[6] Вебер, Х., Г. Херцигер, Лазери - физически основи и приложения, Наука и изкуство, София, 1984

[7] Вейко, В., Технологические лазеры и лазерное излучение, ГУ ИТМО, Санкт-Петербург, 2007

[8] Динев, Ст., Лазерите в модерните технологии, Алфа, София, 1993

[9] Кеворкян, А., Текстилно материалознания и изпитвания, Техн.,София, 1977

[10] Лазов Л., Приложение на лазерите в машиностроенето, МК, AMTEX 07, ТУ Габрово,2007 т. II с. 33-39

[11] Наредба за маркировката за съответствие със съществените технически изисквания към продуктите, Приета с ПМС № 164, обн., ДВ, бр. 66 от 11.08.2000

[12] Хисамиева, Л., и др.“Декорирование поверхности текстильных полимерных материалов с помощью лазерной технологии" Журнал Вестник Казанского технологического университета, стр 127,128, 2012.

[13] Belforte, D., 2015 industrial laser market outperforms global manufacturing instability, Industrial lasers Solutions,

[14] Belforte, D., Marks \& Spencer to become first British retailer to use innovative laser labeling, 18.06.2014,

[15] Bosman, J., Processes and strategies for solid state q-switch laser marking of polymers, PhD Thesis, 2007

[16] Csanák, E., "Sustainable Concepts And Eco-Friendly Technologies In The Denim Industry", 19-20 Nov. 2014, Budapest, Hungary

[17] Gaebler, Fr., M. Schulze,"Sealed $\mathrm{CO}_{2}$ Laser Update Product Trends Driven by Diverse Applications". LTJ June No.3,WILEY-VCH Verlag GmbH\&Co., Weinheim, 2007

[18] Esterves, F, Alonso H., "Effect of $\mathrm{CO} 2$ laser radiation on surface properties of synethics fibres". Research Journal of Textile and Apparel, 11(3):42, 2007

[19] Ferrero F, Testore F, Innocenti R, Tonin C., "Surface degradation of linen textiles induced by laser treatment: comparsion with electron beam and heat source", AUTEX Research Journal. Vol.2(3), 2002
[20] Juciene, M., V. Urbelis, Ž. Juchnevičienè, L.Čepukonè, “The effect of laser technological parameters on the color and structure of denim fabric", TRJ, Vol. (2013) July 12, 2013

[21] Khalil, El., "Sustainable and Ecological Finishing Technology for Denim Jeans", AASCIT Communications (American Association for Science and Technology), 2015, Vol.2, Issue 5 July 10, pp. 159-163

[22] LATI Industria Termoplastici S.p.A., Italy, Laser Marking of Thermoplastics, 05.01.2016

[23] Laser marking technologies, Sintec Optronics Technology Pte Ltd, 2016

[24] Lazov, L., Hr. Deneva, P. Narica, Laser Marking Methods, ISSN 1691-5402, (C) Rezekne Higher Education Institution (Rēzeknes Augstskola), Rezekne 2015

[25] Matthews, J., "Textiles in Three Dimensions: An investigation into processes employing laser technology to form design-led threedimensional textiles", $\mathrm{PhD}$ thesis, Loughborough University, 28 February 2011

[26] Nayak, R., R.Padhye, The use of laser in garment manufacturing: an overview, Fashion and Textiles, Springer Open Journal, 2016

[27] Nourbakhsh, S. \&Ashjaran, A., 2012, 'Laser Treatment of Cotton Fabric for Durable Antibacterial Properties of Silver Nanoparticles', Materials, 5, Pp. 1247-1257

[28] Ortiz-Morales, M.,et.al, "Comparison between Characteristics of Various Laser-based Denim Fading Processes", Optics and Lasers in Engineering, Elsevier, 39, p.15-24, 2003

[29] Overton, G.,D. Belforte, A.Nogee, C.Holton, Laser Marketplace 2015: Lasers surround us in the Year of Light, Tulsa, 01.16.2015

[30] Schuöcker D., Handbook of the Eurolaser Academy, Chapman\& Hall, London, 1998

[31] Schuőcker, D., G. Schuocker, Advanced Laser Materials Processing, CO2 Laser,

[32] SEI Laser Introduces Digital And Eco Sustainable Laser Solutions At ITMA'2015, TWM, 18January 2016

[33] Siegman, A., LASERS, Mill Valley University Science Books, CA, 1986

[34] Solaiman. Md., J. Saha, Comparative Analysis of Manual Fading and Laser Fading Process on Denim Fabric, Science Discovery, Vol.3(6), pp 44-49, Dec. 2015

[35] Steen,M.W., J.Mazumder, Laser Material Processing, Springer, 2010

[36] Štěpánková, M. et.al, "Impact of laser thermal stress on cotton fabric". Fibers and Textiles in Eastern Europe, Vol.18, N3, p.70-73, 2010

[37] Yuan, G., Jiang, S., Newton, E., Fan, J. \& Au, W., 'Fashion Design Using Laser Engraving Technology', 8ISS Symposium-Panel on Transformation, Pp. 65-69

[38] Laserschneiden und -gravieren von Textilen, EurolaserGmbH, avr, 2009, 2 www.avronline.de

[39] Laserbearbeitung für das Automobil-Interieur,urolaserGmbH, avr, 2010, 9 www.avronline.de

[40] US 6753501 B1, Processing of textile materials using laser beams and material sized in larger widths, Jun 22, 2004

[41] www.sp-laser.ru/aktualnye-woprosy-otwety.html [Accessed:30.10.2016]

[42] www.trumpf.com/en.html TRUMPF LaserTechnology, [Accessed: 28.10.2016]

[43] www.markpro.ru/lazer.html Лазерная маркировка, [Accessed: 28.08.2015]

[44] www.dapramarking.com/data-matrix.htm 2D Data Matrix Code Products [Accessed: 26.10.2015]

[45] www.cemark.bg/bg/lazeri/ , [Accessed: 21.11.2016]

[46] www.pulslight.net/laser-marking/ , Pulslight-Laser systems, [Accessed: 20.12.2014]

[47] http://www.goldenlaser.cc/gallery/page/4 [Accessed: 17.04.2017] 